\title{
HUMAN T-LYMPHOTROPIC VIRUS 1 (HTLV-1) AND HUMAN T-LYMPHOTROPIC VIRUS 2 (HTLV-2): GEOGRAPHICAL RESEARCH TRENDS AND COLLABORATION NETWORKS (1989-2012)
}

\author{
Gregorio GONZÁLEZ-ALCAIDE(1), José Manuel RAMOS(2,3), Charles HUAMANí(4), Carmen de MENDOZA(5) \& Vicent SORIANO(5)
}

\begin{abstract}
SUMMARY
Publications are often used as a measure of research work success. Human T-lymphotropic virus (HTLV) type 1 and 2 are human retroviruses, which were discovered in the early 1980s, and it is estimated that 15-20 million people are infected worldwide. This article describes a bibliometric review and a coauthorship network analysis of literature on HTLV indexed in PubMed in a 24-year period. A total of 7,564 documents were retrieved, showing a decrease in the number of documents from 1996 to 2007. HTLV manuscripts were published in 1,074 journals. Japan and USA were the countries with the highest contribution in this field (61\%) followed by France (8\%). Production ranking changed when the number of publications was normalized by population (Dominican Republic and Japan), by gross domestic product (Guinea-Bissau and Gambia), and by gross national income per capita (Brazil and Japan). The present study has shed light on some of the defining features of scientific collaboration performed by HTLV research community, such as the existence of core researchers responsible for articulating the development of research in the area, facilitating wider collaborative relationships and the integration of new authors in the research groups.
\end{abstract}

KEYWORDS: Human T-lymphotropic virus (HTLV); T cell leukemia/lymphoma; Tropical spastic paraparesis; Bibliometrics; Research collaboration.

\section{INTRODUCTION}

Four different types of human T-lymphotropic viruses (HTLV) have been described in humans. Human T-lymphotropic virus type 1 (HTLV-1) was the first retrovirus infecting humans to be discovered in $1980^{1}$, and 15-20 million people are estimated to be infected worldwide ${ }^{2-4}$. Endemic foci of infection have been reported in Japan, Melanesia, Iran, Central and West Africa, the Caribbean, and South America ${ }^{5}$. In Europe, North America, and Australia, HTLV-1 infection is rare and mainly found in immigrants coming from endemic areas, and their sexual partners and descendants ${ }^{6,7}$. Although most HTLV-1-infected people remain asymptomatic throughout their lives, approximately $3 \%$ develop adult T cell leukemia/lymphoma (ATLL) and another 3\% develop HTLV-1associated myelopathy/tropical spastic paraparesis (HAM/TSP) ${ }^{8}$.

HTLV-2 was discovered in 1982, and it is estimated that 3-5 million people are chronically infected. It is mostly prevalent among intravenous drug users in North America and Western Europe, although endemic infections can be found in some Amerindian and African pygmy tribes. In contrast to HTLV-1, the pathogenicity of HTLV-2 is very low and has only occasionally been linked to subacute neurological syndromes, including HTLV-2-like paraparesis, neuropathies, and bladder disturbances ${ }^{7,9-14}$.
In 2005, HTLV type 3 (HTLV-3) was discovered in two asymptomatic inhabitants from South Cameroon. More recently, two other cases of HTLV-3 infection in people living in Cameroon were reported, suggesting that this virus is not extremely rare in the human population living in Central Africa ${ }^{15}$. Finally, only one strain of HTLV-4 has been identified in a person who also lived in Cameroon ${ }^{16}$.

The basic premise for bibliometrics is that scientific knowledge is mainly transmitted through publications that report research results, which in turn allowed us to analyze the development of the scientific field in question. By carrying out a quantitative analysis of scientific publications in a given field, we can draw conclusions on how that research field evolves and develops ${ }^{17,18}$.

There have been publications analyzing research production for other viral infections, such as John Cunningham virus ${ }^{19}$, Nipah virus ${ }^{20}$, avian influenza virus ${ }^{21}$, H1N1 influenza virus ${ }^{22}$, and papillomavirus ${ }^{23}$ among others. As for HTLV, one short quantitative study analyzing research output for the period between 2001 and 2010 using the PubMed was reported at an international conference as a poster presentation ${ }^{24}$. Another study analyzed scientific production in the field of the motor neuron diseases, Konzo and neurolathyrism, in comparison with HTLV-

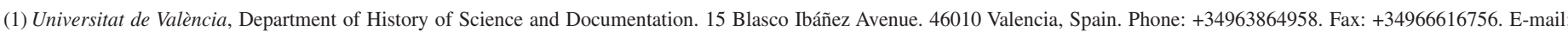
gregorio.gonzalez@uv.es

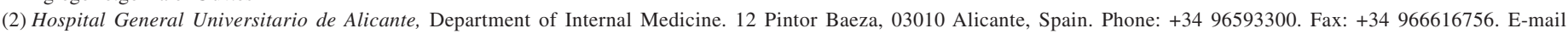
jramosrincon@yahoo.es

(3) Universidad Miguel Hernández de Elche, Department of Medicine. Universidad Avenue 03202 Elche, Alicante, Spain.

(4) Instituto Nacional de Salud, Lima, 1154, Av. Arriba Peru, Lima 42, Peru. Phone: +51-992814710. E-mail: huamani_ca@ hotmail.com

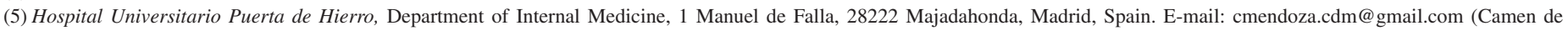
Mendoza), vsoriano@dragonet.es (Vicent Soriano).

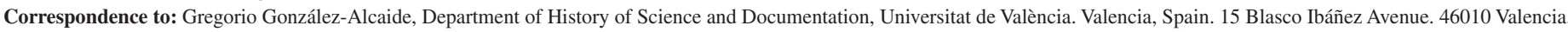
Spain. Phone: +34 9638649 58. Fax: +34 9666167 56. E-mail: gregorio.gonzalez@uv.es 


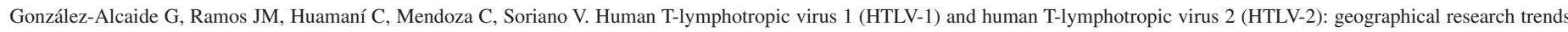
and collaboration networks (1989-2012). Rev Inst Med Trop Sao Paulo. 2016;58: 11

1/ HAM/TSP over 21 years (from 1990 to 2010) through the Web of Science database ${ }^{25}$. As HTLV-1 can be considered a neglected public health problem ${ }^{26}$, and ATLL and HAM/TSP can be considered neglected diseases, this would provide more focus on this condition ${ }^{27}$.

The aim of this study was to investigate HTLV research output using PubMed database, covering a period of 24 years (1989-2012): by journal of publication, country, forms of disease, author production, and collaboration patterns.

\section{METHODS}

The Medline database, accessible and free of charge through the PubMed platform, was selected as the most suitable database to search for HTLV publications, due to its volume and coverage. PubMed was accessed online in December 28, 2013. For retrieving documents, a search was made comprising the MeSH terms or descriptors: "Human T-lymphotropic virus 1", "Human T-lymphotropic virus 2", "Human T-lymphotropic virus 3", "HTLV-II Antigens", "HTLV-II Antibodies", "HTLV-I Antigens", "HTLV-I Antibodies", "HTLV-II Infections", and "HTLV-I Infections". The study period was from January 1, 1989 to December 31, 2012. We decided to begin in 1989 because a different HTLV MeSH term was introduced in 1989. No language or document type restriction was considered in the search, so that publication patterns for all publications on HTLV could be analyzed.

The document type used in our study refers to the type of article according to PubMed (journal article, letter, editorial, review, etc.). Financial support was analyzed.

Productivity by country was analyzed considering the number of papers and percentage of world production. It should be noted that institutional affiliation is only included for the first participating author in the PubMed database in Journal articles and Reviews. Indicators for each country's productivity between 1989 and 2012 were standardized with respect to the median population, gross domestic product (GDP), GDP per capita and health expenditure (HE) per capita. To calculate the publications per million inhabitants (population index), per 10 billion US dollars of GDP (GDP index), per 1,000 US dollars of GDP per capita (GDP per capita index), and per 100 US dollars of HE per capita (HE per capita index), data were obtained from World Development Indicators from the World Bank online databases ${ }^{28}$.

Based on geographical, scientific, and economic criteria, the world was divided into six regions according to the composition of macrogeographical (continental) regions, geographical subregions, and selected economic regions and other unidata groupings from the United Nations Statistics Division ${ }^{29}$. The forms of diseases were classified as HTLV-I, HTLV-II, ATLL and HAM/TSP according to the MeSH term.

A number of widely used bibliometric indicators were calculated to characterize the scientific collaboration on HTLV, the percentage of documents signed in collaboration and the average number of coauthors per paper. A coauthorship network analysis was carried out. Coauthorship networks are made up of nodes (authors) and ties between them (coauthorship links). We identified the nodes that function as "cutpoints" or intermediates facilitating connectivity between parts of the network that would otherwise be unconnected, and we also made different statistical calculations relating to centrality. These indicators are commonly used in Social Network Analysis (SNA) and include the concept of "degree" and "betweenness," used to characterize the role played by different investigators in the network and to determine the most important and influential authors in it. BibExcel software was used for the treatment and standardization of the bibliographical information, and the Pajek program was used to analyze and generate a visualization of the coauthorship network.

The Committee for Security of Information and Research at the Hospital General Universitario de Alicante provided ethical approval for this study.

\section{RESULTS}

In the PubMed database, a total of 7,564 references were retrieved during the entire study period. The number of documents decreased during the overall study period; the global figures per six-year period are as follows: 2,717 (35.9\%) publications from 1989 to $1994 ; 2,236(29.6 \%)$ from 1995 to $2000 ; 1,387$ (18.3\%) from 2001 to 2006; and 1,224 from 2007 to 2012 (16.2\%) (Fig. 1).

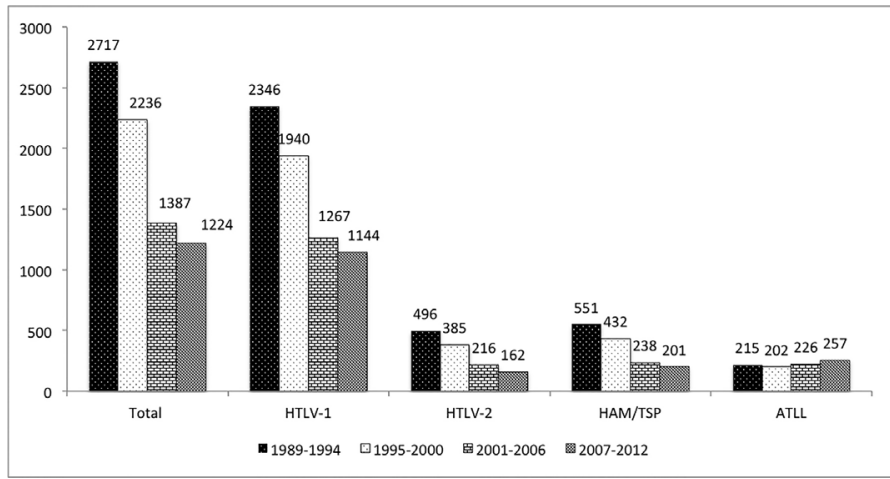

Fig. 1 - Number of HTLV research publications in PubMed between 1989 and 2012, per 6-year period.

Language and type of documents: The primary language was English $(89.1 \%)$, followed by Japanese $(5.1 \%)$, Spanish $(2.0 \%)$, and French $(1.7 \%)$. The main type of document was "Original paper contribution" (77.8\%), followed by "Review" (11.7\%), and "Letter" $(8.5 \%)$. Almost $53 \%$ of documents were original researches, only $0.8 \%$ were clinical trials, and $0.04 \%$ were meta-analysis studies.

Journal of publication: The 7,564 retrieved articles were published in 1,074 different scientific journals. Ten journals accounted for $25.8 \%$ of HTLV journal literature. About one half of the articles was concentrated in 44 journals, while the remaining half was spread over 1,030 journals. Moreover, 498 journals published only one paper on HTLV. The journals area mainly include the fields of virology $(n=10)$, hematology $(n=9)$, immunology $(n=8)$, oncology $(n=7)$, clinical neurology $(n=5)$, and infectious diseases $(n=5)$ among others.

Topics and MeSH: The MeSH "Human T-lymphotropic virus 1", "HTLV infection", "HTLV-I Antibodies", "HTLV-II Infections", "Human T-lymphotropic virus 2", "HTLV-II Antibodies", "HTLV-I Antigens", and "HTLV-II Antigens" were reported in 62.8\%, 40.7\%, 14.8\%, 10.4\%, 


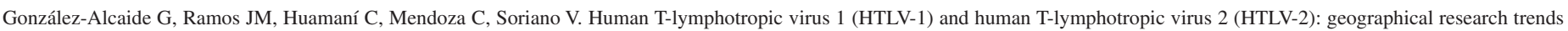
and collaboration networks (1989-2012). Rev Inst Med Trop Sao Paulo. 2016;58:11.

$10.1 \%, 3.8 \%, 2.6 \%$, and $0.4 \%$ of articles respectively. About $88.5 \%$ of documents $(\mathrm{n}=6,697)$ were about HTLV-I, $16.6 \%$ of documents $(\mathrm{n}=$ 1,259 ) were about HTLV-II, and $12.3 \%$ of documents referred to both HTLV-I and HTLV-II.

The main MeSH infections associated with HTLV were: "Paraparesis, Tropical Spastic" (18.8\%), "Leukemia-Lymphoma, Adult T-Cell" (11.9\%), "Leukemia, T-Cell” (4.8\%), "Skin Neoplasms" (1.4\%), and "Uveitis" (1.2\%). The main MeSH associated with virology of HTLV were: "Molecular Sequence Data" (15.9\%), "Gene Products, tax" (13.8\%), "DNA viral" (12.2\%), "Cell Line" (12.1\%), and "Base sequence" (11.9\%). The MeSH "HIV 1", "HIV Infections", "HIV-2", "HIV", "HIV antibodies", and "HIV seropositivity" were reported in $7.5 \%, 5.8 \%, 1.8 \%, 1.8 \%, 1.7 \%$, and $1.5 \%$ of documents.

Countries of publication: Authors' affiliation was available in 6,590 of the 7,564 documents recovered $(87.1 \%)$. Table 1 ranks countries in crude numbers of retrieved articles and numbers corrected by population index, GDP index, GNI per capita index, and HE per capita index. The first and second countries were Japan and USA, respectively, accounting for more than $61 \%$ of publications, followed by France, Brazil, and United Kingdom. When normalized by population, the order of prominence was Dominica, Japan, Jamaica, Curacao, and Grenada. Once normalized by GDP, we found that among low and middle-income countries, Guinea-Bissau, Gambia, Dominica, Jamaica, and Saint Vincent and the Grenadines were the most productive. If we calculate the ratio of the number of HTLV publications to GDP per capita, Brazil, Japan, USA, China, and India were the most productive. When normalized by HE per capita, the leading order was Brazil, Japan, India, China, and Democratic Republic of the Congo.

Asia and North America were by far the most productive continents in the field of HTLV, responsible for $64.4 \%$ of all articles (Table 1). The ranking corrected by population ranked North America and Europe in first position, and when normalized by GDP, the order of prominence was Latin America and the Caribbean, followed by North America. Once normalized by GDP per capita, the leading order was North America and Asia, and after being normalized by HE per capita, Asia and North America were the most productive (Table 1).

Japan and USA were the most productive countries regarding HTLV1. USA ranked first in HTLV-II followed by Brazil. Japan followed by USA and Brazil were the most productive in HAM/TSP. In ATLL, Japan followed by USA and France were in the lead. Asia, North America, and Europe ranked first in HTLV-I and ATLL; North America, Europe, Latin America and the Caribbean led in HTLV-II; and Asia, North America, and Latin America and the Caribbean had the highest number of publications in HAM/TSP (Table 2).

Authorship: Table 3 ranks the 20 most productive authors for each form of the disease. For global HTLV research, the main author was M. Osame, a Japanese researcher ( $\mathrm{n}=217$ documents), followed by A. Gessain $(\mathrm{n}=158)$, a French investigator, and Y. Tanaka $(\mathrm{n}=150)$, another Japanese scientist. For HTLV-1, the main author was M. Osame $(\mathrm{n}=146)$, Y. Tanaka $(\mathrm{n}=142)$ and A. Gessain $(\mathrm{n}=141)$. In HTLV-2, the main author was R.B. Lal $(n=64)$, a North American researcher, followed by E.L. Murphy $(\mathrm{n}=58)$, another North American investigator and V. Soriano $(n=48)$, a Spanish scientist. M. Osame $(n=170)$ led in
HAM/TSP research, while M. Matsuoka $(n=48)$ led in ATLL research.

Collaboration networks: Nearly all of the "original paper contributions" (96.66\%, $\mathrm{n}=5,671)$ were signed in collaboration, at an average number of $6.2 \pm 3.0$ coauthors per paper. The evolution through time shows a steady increase in collaborative work, rising from an average of $5.6 \pm 2.8$ authors per work in 1989 to $7.2 \pm 4.0$ in 2012 .

Virtually all of the authors (99.7\%) established at least one collaborative link; on average, they collaborated with 11.7 other authors on different papers. Among the most productive authors ( $>9$ papers), this number was considerably higher, at $71.6 \pm 56.6$. However, these authors only had consolidated, stable ties with a handful of colleagues; the average number of collaborators with whom they had signed eight or more papers was $2.4 \pm 3.0$.

Quantifying the different author pairs, we identified 88,919 coauthorship links. Most of these collaborations were isolated, as $83.3 \%$ $(\mathrm{n}=74,063)$ were limited to coauthoring one paper, whereas $9.8 \%$ ( $\mathrm{n}$ $=8,763)$ of the pairs coincided twice and 6.3\% $(n=5,673)$ of the ties were present in 3-9 papers.

Only $420(0.5 \%)$ of the coauthorships occurred in 10 or more documents. An analysis and graphical representation of all the coauthorship links in the form of a network show that $85.1 \%(\mathrm{n}=$ 12,952) of the authors appear interconnected, either directly or through intermediates in a larger research group or in a main component.

We applied a collaboration threshold of eight or more coauthored articles in order to identify and analyze the main research groups, with the most consolidated relationships among its members. We were able to identify 80 clusters, made up of 516 authors. One large group stands out, bringing together 174 authors and six other clusters, each of which consists of more than nine authors. The authors that participate in these clusters are specialized in the study of the same disease in the same geographical proximity; they come primarily from Japan, the USA, and a few European countries, including Belgium, France, and Spain. Calculating the centrality measures used in SNA and identifying the cutpoints it was possible to show how some authors exercise a prominent role as intermediates, bringing together a high number of investigators, or facilitating links between dispersed authors and research foci in the network. Y. Tanaka heads the ranking by betweenness (indicator of the node's centrality in the network), followed by C.R.M. Bangham, S. Kamihira, K. Yamaguchi, and Y. Yamada. M. Osame is the first in degree (number of ties that a vertex has to other vertices in its network), followed by S. Izumo, T. Nakamura, A. Gessain, V. Soriano, Y. Tanaka, and E.L. Murphy. Table 4 lists the top 17 authors ranking according betweenness and degree of centrality measures as well as the number of published original articles, and Fig. 2 is a graphical visualization of the main research foci, with labels to identify the most prominent authors.

\section{DISCUSSION}

Some authors have highlighted the importance of HTLV-1-associated myelopathy/tropical spastic paraparesis, the main disease associated with HTLV-1, that many consider to be neglected ${ }^{27}$. Its burden is overwhelmingly concentrated (with the exception of Japan) in poor countries; there is no adequate intervention for its prevention or treatment, 
González-Alcaide G, Ramos JM, Huamaní C, Mendoza C, Soriano V. Human T-lymphotropic virus 1 (HTLV-1) and human T-lymphotropic virus 2 (HTLV-2): geographical research trends and collaboration networks (1989-2012). Rev Inst Med Trop Sao Paulo. 2016;58:11.

Table 1

Top 20 countries and world regions ranked according to total number of publications, publications per inhabitant, per gross domestic product (GDP), GDP per capita and health expenditure (HE) per capita in 6,590 human T-lymphotrophic virus manuscripts with institutional address of the first author.

\begin{tabular}{|c|c|c|c|c|c|c|c|c|c|}
\hline Country & $\begin{array}{l}\text { N. of docs. } \\
(\%)\end{array}$ & Country & $\begin{array}{l}\text { Population } \\
\text { index* }\end{array}$ & Country & $\begin{array}{c}\text { GDP } \\
\text { index }^{* *}\end{array}$ & Country & $\begin{array}{c}\text { GDP per } \\
\text { capita } \\
\text { index*** }\end{array}$ & Country & $\begin{array}{c}\text { HE per } \\
\text { capita } \\
\text { index**** }\end{array}$ \\
\hline 1.Japan & $2,116(32.1)$ & 1.Dominica & 28.27 & 1.Guinea-Bissau & 175.81 & 1.Brazil & 78.57 & 1.Brazil & 90.28 \\
\hline 2.USA & $1,952(29.6)$ & 2.Japan & 16.74 & 2.Gambia & 82.63 & 2.Japan & 59.58 & 2.Japan & 74.25 \\
\hline 3.France & $524(8.0)$ & 3.Jamaica & 14.78 & 3.Dominica & 63.39 & 3.USA & 52.83 & 3.India & 57.65 \\
\hline 4.Brazil & $415(6.3)$ & 4.Curaçao & 14.44 & 4.Jamaica & 42.39 & 4.China & 26.09 & 4.China & 48.99 \\
\hline 5.UK & $248(3.8)$ & 5.Grenada & 9.86 & 5.St.Vincent ${ }^{\#}$ & 41.75 & 5.India & 25.46 & 5.Congo & 43.84 \\
\hline 6.Italy & 194 (2.9) & 6.St.Vincent ${ }^{\# \#}$ & 9.23 & 6.Grenada & 23.11 & 6.Guinea-Bissau & 24.15 & 6.Guinea-Bissau & 34.14 \\
\hline 7.Germany & $106(1.6)$ & 7.Gabon & 8.78 & 7.Gabon & 20.06 & 7.Congo & 23.01 & 7.Mozambique & 33.97 \\
\hline 8.Canada & $85(1.3)$ & 8.France & 8.51 & 8.Lebanon & 13.76 & 8.Mozambique & 22.03 & 8.USA & 32.58 \\
\hline 9.Spain & $77(1.2)$ & 9.Israel & 7.46 & 9.Mozambique & 13.60 & 9.France & 18.03 & 9.South Korea & 28.14 \\
\hline 10.Belgium & $60(0.9)$ & 10.Lebanon & 7.45 & 10.Central A. R. & 10.89 & 10.Nigeria & 14.22 & 10.Gambia & 27.80 \\
\hline 11.Chile & $54(0.8)$ & 11.USA & 6.92 & 11.Senegal & 7.33 & 11.Peru & 13.72 & 11.Peru & 26.20 \\
\hline 12.Israel & $47(0.7)$ & 12.Guinea-Bissau & 6.15 & 12.South Korea & 6.54 & 12.Jamaica & 11.06 & 12.Ethiopia & 24.58 \\
\hline 13.China & $45(0.7)$ & 13.Belgium & 5.78 & 13. Trinidad ${ }^{\#}$ & 6.28 & 13.Gambia & 10.45 & 13.Jamaica & 19.90 \\
\hline 14.Australia & $42(0.6)$ & 14.Denmark & 5.61 & 14.Peru & 5.13 & 14.Ethiopia & 9.88 & 14.Tanzania & 17.95 \\
\hline 15.Argentina & $41(0.6)$ & 15. Trinidad ${ }^{\#}$ & 4.70 & 15.Togo & 5.06 & 15.Iran & 9.38 & 15.Nigeria & 17.80 \\
\hline 16.Peru & $39(0.6)$ & 16.Gambia & 4.67 & 16.Chile & 5.05 & 16.Tanzania & 9.32 & 16.France & 15.36 \\
\hline 17.Jamaica & $38(0.6)$ & 17.UK & 4.17 & 17.Congo ${ }^{\# \#}$ & 5.04 & 17.UK & 8.62 & 17.Cameroon & 14.25 \\
\hline 18.Sweden & $33(0.5)$ & 18.Ireland & 3.80 & 18.Japan & 4.71 & 18.Chile & 8.12 & 18.Ghana & 14.11 \\
\hline 19.Netherlands & $31(0.5)$ & 19. Barbados & 3.71 & 19.Brazil & 4.33 & 19.Ghana & 7.80 & 19.Bangladesh & 13.97 \\
\hline 20.Denmark & $30(0.5)$ & 20.Sweden & 3.69 & 20.Cameroon & 4.11 & 20.Italy & 7.59 & 20.Senegal & 12.76 \\
\hline World region & N. of docs. & World region & $\begin{array}{l}\text { Population } \\
\text { index* }\end{array}$ & World region & $\begin{array}{l}\text { GDP in- } \\
\text { dex** }\end{array}$ & World region & $\begin{array}{c}\text { GNI per } \\
\text { capita } \\
\text { index } * * *\end{array}$ & World region & $\begin{array}{c}\text { HE per } \\
\text { capita } \\
\text { index**** }\end{array}$ \\
\hline 1.Asia & $2,223(33.7)$ & 1.North America & 6.50 & $\begin{array}{l}\text { 1.Latin America \& } \\
\text { the Caribbean }\end{array}$ & 2.43 & 1.North America & 30.68 & 1.Asia & 31.69 \\
\hline 2.North America & $2,037(30.9)$ & 2.Europe & 1.95 & 2.North America & 1.76 & 2.Asia & 12.43 & 2.North America & 22.33 \\
\hline 3.Europe & $1,419(21.5)$ & 3.Oceania & 1.73 & 3.Sub-Saharan Africa & 1.69 & $\begin{array}{l}\text { 3.Latin America } \\
\text { \& the Caribbean }\end{array}$ & 2.29 & $\begin{array}{l}\text { 3.Latin America } \\
\& \text { the Caribbean }\end{array}$ & 6.00 \\
\hline $\begin{array}{l}\text { 4.Latin America \& } \\
\text { the Caribbean }\end{array}$ & $658(10.0)$ & $\begin{array}{l}\text { 4.Latin America } \\
\text { \& the Caribbean }\end{array}$ & 1.23 & 4.Asia & 1.17 & 4.Europe & 1.44 & $\begin{array}{l}\text { 4.Sub-Saharan } \\
\text { Africa }\end{array}$ & 2.53 \\
\hline 5.North Africa & $125(1.9)$ & 5.Asia & 0.66 & 5.Europe & 1.10 & $\begin{array}{l}\text { 5.Sub-Saharan } \\
\text { Africa }\end{array}$ & 1.38 & 5.Europe & 1.99 \\
\hline $\begin{array}{l}\text { 6.Sub-Saharan } \\
\text { Africa }\end{array}$ & $86(1.3)$ & 6.North Africa & 0.30 & 6.North Africa & 0.73 & 6.North Africa & 0.64 & 6.North Africa & 1.46 \\
\hline 7.Oceania & $42(0.6)$ & $\begin{array}{l}\text { 7.Sub-Saharan } \\
\text { Africa }\end{array}$ & 0.14 & 7.Oceania & 0.61 & 7.Oceania & 0.53 & 7.Oceania & 0.70 \\
\hline Total & $6,590(100)$ & Total & 1.08 & Total & 1.66 & Total & 3.22 & Total & 5.21 \\
\hline
\end{tabular}

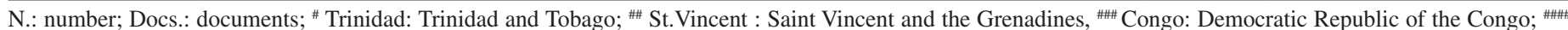
Central A. R.: Central African Republic; * Number of publications per million of population; ** Number of publications per 10 billion US dollars of gross domestic product (GDP); *** Number of publications per 1000 US dollars of GDP per capita; **** Number of publications per 100 US dollars of Health expenditure per capita.

and neither the pharmaceutical industry nor other private funders have invested much in research on the topic ${ }^{26}$. Moreover, few studies offer current data on the disease's prevalence or incidence in countries where it is endemic or on the high proportion of underdiagnosed cases and late diagnosis a consequence of its asymptomatic nature. There is also a dearth of studies investigating treatments for the diseases associated with the virus ${ }^{3}$. The formal consideration of tropical spastic paraparesis (and by extension, HTLV) as a neglected disease would be in the interest of researchers on the topic, providing as the classification has for other neglected diseases an impulse for new studies. The most prominent, current authors and research groups on HTLV could then become reference points, facilitating the integration of new investigators. 


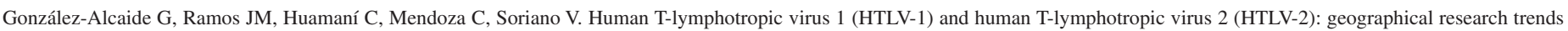
and collaboration networks (1989-2012). Rev Inst Med Trop Sao Paulo. 2016;58:11.

Table 2

Top 20 countries and world regions ranked according to total number of publications by forms of human T-lymphotrophic virus (HTLV) types and diseases

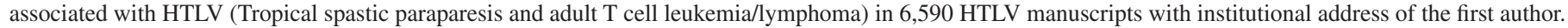

\begin{tabular}{|c|c|c|c|c|c|c|c|c|c|c|c|}
\hline \multicolumn{3}{|c|}{ HTLV-1 } & \multicolumn{3}{|c|}{ HTLV-2 } & \multicolumn{3}{|c|}{ Tropical spastic paraparesis } & \multicolumn{3}{|c|}{ Adult T cell leukemia/lymphoma } \\
\hline Country & $\begin{array}{l}\text { N. of } \\
\text { docs. }\end{array}$ & $\%$ & Country & $\begin{array}{l}\text { N. of } \\
\text { docs. }\end{array}$ & $\%$ & Country & $\begin{array}{l}\text { N. of } \\
\text { docs. }\end{array}$ & $\%$ & Country & $\begin{array}{l}\text { N. of } \\
\text { docs. }\end{array}$ & $\%$ \\
\hline Japan & 1,858 & 31.7 & USA & 459 & 43.6 & Japan & 473 & 37.7 & Japan & 417 & 51.4 \\
\hline USA & 1,738 & 29.7 & Brazil & 110 & 10.4 & USA & 235 & 18.7 & USA & 195 & 24.0 \\
\hline France & 499 & 8.5 & France & 78 & 7.4 & Brazil & 167 & 13.3 & France & 53 & 6.5 \\
\hline Brazil & 343 & 5.9 & Japan & 65 & 6.2 & France & 92 & 7.3 & Brazil & 30 & 3.7 \\
\hline UK & 232 & 4.0 & Italy & 63 & 6.0 & UK & 65 & 5.2 & UK & 16 & 2.0 \\
\hline Italy & 162 & 2.8 & Spain & 37 & 3.5 & Chile & 32 & 2.5 & Germany & 14 & 1.7 \\
\hline Germany & 101 & 1.7 & Argentina & 30 & 2.8 & Italy & 17 & 1.4 & Lebanon & 12 & 1.5 \\
\hline Canada & 74 & 1.3 & UK & 25 & 2.4 & Canada & 17 & 1.4 & Italy & 9 & 1.1 \\
\hline Spain & 62 & 1.1 & Belgium & 23 & 2.2 & Spain & 16 & 1.3 & Canada & 8 & 1.0 \\
\hline Belgium & 51 & 0.9 & Canada & 13 & 1.2 & Jamaica & 15 & 1.2 & China & 6 & 0.7 \\
\hline Israel & 44 & 0.8 & Netherlands & 13 & 1.2 & Germany & 14 & 1.1 & Chile & 5 & 0.6 \\
\hline Chile & 43 & 0.7 & Sweden & 12 & 1.1 & Peru & 12 & 1.0 & Iran & 5 & 0.6 \\
\hline China & 43 & 0.7 & Peru & 10 & 0.9 & Colombia & 11 & 0.9 & Greece & 4 & 0.5 \\
\hline Australia & 37 & 0.6 & Germany & 9 & 0.9 & Israel & 8 & 0.6 & Peru & 3 & 0.4 \\
\hline Peru & 37 & 0.6 & Ireland & 9 & 0.9 & Belgium & 6 & 0.5 & Colombia & 3 & 0.4 \\
\hline Argentina & 34 & 0.6 & Mexico & 8 & 0.8 & Australia & 6 & 0.5 & Argentina & 3 & 0.4 \\
\hline Jamaica & 33 & 0.6 & Israel & 6 & 0.6 & Sweden & 6 & 0.5 & Netherlands & 3 & 0.4 \\
\hline Netherlands & 31 & 0.5 & Norway & 6 & 0.6 & South Africa & 6 & 0.5 & Senegal & 3 & 0.4 \\
\hline Denmark & 30 & 0.5 & Cuba & 5 & 0.5 & Argentina & 4 & 0.3 & Spain & 2 & 0.2 \\
\hline Sweden & 29 & 0.5 & Saudi Arabia & 5 & 0.5 & China & 3 & 0.2 & Jamaica & 2 & 0.2 \\
\hline \multicolumn{3}{|c|}{ HTLV-1 } & \multicolumn{3}{|c|}{ HTLV-2 } & \multicolumn{3}{|c|}{ Tropical spastic paraparesis } & \multicolumn{3}{|c|}{ Adult T cell leukemia/lymphoma } \\
\hline World region & $\begin{array}{l}\text { N. of } \\
\text { docs. }\end{array}$ & $\%$ & World region & $\begin{array}{l}\text { N. of } \\
\text { docs. }\end{array}$ & $\%$ & World region & $\begin{array}{l}\text { N. of } \\
\text { docs. }\end{array}$ & $\%$ & World region & $\begin{array}{l}\text { N. of } \\
\text { docs. }\end{array}$ & $\%$ \\
\hline Asia & 1,960 & 33.5 & North America & 472 & 44.8 & Asia & 482 & 45.8 & Asia & 426 & 40.5 \\
\hline North America & 1,812 & 30.9 & Europe & 295 & 28.0 & North America & 252 & 23.9 & North America & 203 & 19.3 \\
\hline Europe & 1,299 & 22.2 & $\begin{array}{c}\text { Latin America \& } \\
\text { the C. }\end{array}$ & 175 & 16.6 & $\begin{array}{c}\text { Latin America \& } \\
\text { the C. }\end{array}$ & 251 & 23.8 & Europe & 110 & 10.4 \\
\hline $\begin{array}{c}\text { Latin America \& } \\
\text { the C. }\end{array}$ & 550 & 9.4 & Asia & 78 & 7.4 & Europe & 230 & 21.8 & $\begin{array}{c}\text { Latin America \& } \\
\text { the C. }\end{array}$ & 47 & 4.5 \\
\hline North Africa & 113 & 1.9 & North Africa & 18 & 1.7 & $\begin{array}{c}\text { Sub-Saharan } \\
\text { Africa }\end{array}$ & 21 & 2.0 & North Africa & 19 & 1.8 \\
\hline $\begin{array}{c}\text { Sub-Saharan } \\
\text { Africa }\end{array}$ & 80 & 1.4 & $\begin{array}{c}\text { Sub-Saharan } \\
\text { Africa }\end{array}$ & 10 & 0.9 & North Africa & 14 & 1.3 & $\begin{array}{c}\text { Sub-Saharan } \\
\text { Africa }\end{array}$ & 7 & 0.7 \\
\hline Oceania & 37 & 0.6 & Oceania & 4 & 0.4 & Oceania & 6 & 0.5 & Oceania & 0 & 0.0 \\
\hline Total & 5,855 & 100 & Total & 1,053 & 100 & Total & 1,256 & 100 & Total & 812 & 100 \\
\hline
\end{tabular}

N.: number; Docs.: documents; Latin America \& C.: Latin America \& the Caribbean.

This study has shown a decrease in the number of publications on HTLV over a 24 year period (1989-2012). Most scientific production has increased over the last few years, although others ${ }^{19,23}$, like leprosy, have experienced reduced trends since the turn of the century ${ }^{34}$. There are different explanations for this decrease, the first of which being the decrease in the prevalence of HTLV infection due to the control of virus transmission, especially in Japan ${ }^{1}$. Secondly, the discovery of HIV-1 infection in 1983 and the worldwide morbidity and mortality impact of AIDS has led to almost all resources being concentrated on this disease in the last two decades. In addition, most retrovirologists have focused on the HIV field and HTLV infection has been forgotten. Thirdly, since the disease associated with HTLV-2, and HAM/TSP or ATLL associated with HTLV-1 infection are poorly prevalent and do not have an effective therapy ${ }^{3,6}$, there is not much research interest within the scientific community. Finally, there is no effective antiretroviral therapy in contrast to other infections like HIV, herpesvirus or hepanavirus, and 
González-Alcaide G, Ramos JM, Huamaní C, Mendoza C, Soriano V. Human T-lymphotropic virus 1 (HTLV-1) and human T-lymphotropic virus 2 (HTLV-2): geographical research trends and collaboration networks (1989-2012). Rev Inst Med Trop Sao Paulo. 2016;58:11.

Table 4

Top 17 authors based on centrality measures and the total number of publications.

\begin{tabular}{lccccc}
\hline Rank & Author & Betweenness & Author & Degree & Author \\
\hline 1 & Tanaka, Yuetsu & 0.000071 & Osame, Mitsuhiro & 27 & Osame, Mitsuhiro \\
2 & Bangham, Charles RM & 0.000056 & Izumo, Shuji & 20 & Tanaka, Yuetsu \\
3 & Kamihira, Shimeru & 0.000053 & Nakamura, Tatsufumi & 18 & Gessain, Antoine \\
4 & Yamaguchi, Kazunari & 0.000050 & Gessain, Antoine & 17 & Izumo, Shuji \\
5 & Yamada, Yasuaki & 0.000047 & Soriano, Vicente & 17 & 121 \\
6 & Okayama, Akihiko & 0.000039 & Tanaka, Yuetsu & 16 & Jacobson, Steven \\
7 & Osame, Mitsuhiro & 0.000032 & Murphy, Edward L & 15 & Lal, Renu B \\
8 & Fujii, Masahiro & 0.000029 & Yamada, Yasuaki & 14 & Murphy, Edward L \\
9 & Kannagi, Mari & 0.000028 & Kamihira, Shimeru & 13 & Yamaguchi, Kazunari \\
10 & Izumo, Shuji & 0.000020 & Bangham, Charles RM & 12 & Bangham, Charles RM \\
11 & Hisada, Michie & 0.000019 & Nagataki, S & 12 & 77 \\
12 & Utsunomiya, Atae & 0.000017 & Usuku, Koichiro & 11 & Blattner, WA \\
13 & Yamamoto, Naoki & 0.000016 & Yamamoto, Naoki & 11 & Taylor, Graham P \\
14 & Murphy, Edward L & 0.000016 & Yamaguchi, Kazunari & 10 & Nakamura, Tatsufumi \\
15 & Sonoda, Shunro & 0.000016 & Okayama, Akihiko & 10 & Yamamoto, Naoki \\
16 & Uozumi, Kimiharu & 0.000016 & Eguchi, Katsumi & 10 & 65 \\
17 & Hanchard, Barrie & 0.000013 & Tomonaga, Masao & 10 & 62 \\
\hline
\end{tabular}

Table 3

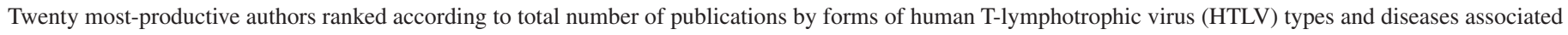
with HTLV (Tropical spastic paraparesis and adult T cell leukemia/lymphoma).

\begin{tabular}{|c|c|c|c|c|c|c|c|c|c|}
\hline \multirow[b]{2}{*}{ Author } & \multirow{2}{*}{$\begin{array}{l}\text { Total } \\
\begin{array}{l}\text { N. of } \\
\text { docs. }\end{array}\end{array}$} & \multicolumn{2}{|c|}{ HTLV-1 $(\mathrm{n}=6,697)$} & \multicolumn{2}{|c|}{ HTLV-2 $(\mathrm{n}=1,259)$} & \multicolumn{2}{|c|}{$\begin{array}{l}\text { Tropical spastic paraparesis } \\
(\mathrm{n}=1,422)\end{array}$} & \multicolumn{2}{|c|}{$\begin{array}{l}\text { Adult T cell leukemia/lym- } \\
\text { phoma }(\mathrm{n}=900)\end{array}$} \\
\hline & & Author & $\begin{array}{l}\text { N. of } \\
\text { docs. }\end{array}$ & Author & $\begin{array}{l}\text { N. of } \\
\text { docs. }\end{array}$ & Author & $\begin{array}{l}\text { N. of } \\
\text { docs. }\end{array}$ & Author & $\begin{array}{l}\text { N. of } \\
\text { docs. }\end{array}$ \\
\hline Osame, M & 217 & Osame, M & 146 & Lal, RB & 64 & Osame, M & 170 & Matsuoka, M & 48 \\
\hline Gessain, A & 158 & Tanaka, Y & 142 & Murphy, EL & 58 & Izumo, S & 91 & Yamada, Y & 42 \\
\hline Tanaka, Y & 150 & Gessain, A & 141 & Soriano, V & 48 & Jacobson, $S$ & 77 & Mori, $\mathrm{N}$ & 39 \\
\hline Jacobson, S & 112 & Jacobson, $\mathrm{S}$ & 96 & Gessain, A & 40 & Usuku, K & 56 & Tomonaga, M & 37 \\
\hline Izumo, $\mathrm{S}$ & 110 & Lairmore, MD & 95 & Kaplan, JE & 39 & Nakamura, T & 51 & Tanaka, Y & 34 \\
\hline Lairmore, MD & 103 & Yamaguchi, K & 95 & Hall, WW & 35 & Bangham, CRM & 45 & Utsunomiya, A & 27 \\
\hline Yamaguchi, K & 99 & Bangham, CRM & 92 & Poiesz, BJ & 33 & Cartier, L & 41 & Kamihira, S & 26 \\
\hline Bangham, CRM & 96 & Izumo, S & 83 & Green, PL & 30 & Kubota, R & 40 & Yamaguchi, K & 25 \\
\hline Lal, RB & 93 & Matsuoka, M & 80 & Rudolph, DL & 30 & Araújo, AQC & 35 & Gessain, A & 22 \\
\hline Blattner, WA & 86 & Blattner, WA & 75 & De Thé, G & 28 & Gessain, A & 33 & Kannagi, M & 22 \\
\hline Murphy, EL & 85 & Taylor, GP & 74 & Khabbaz, RF & 28 & Saito, M & 32 & Ohshima, K & 22 \\
\hline Soriano, V & 84 & Franchini, G & 70 & Vandamme, AM & 27 & Itoyama, Y & 31 & Ikeda, S & 21 \\
\hline Matsuoka, M & 83 & Mori, N & 69 & Bertazzoni, U & 25 & Nagataki, S & 29 & Hermine, $\mathrm{O}$ & 21 \\
\hline Taylor, GP & 80 & Jeang, K-T & 68 & Lairmore, MD & 24 & Kira, JI & 29 & Masuda, M & 21 \\
\hline Nakamura, T & 76 & Lal, RB & 67 & Chen, IYS & 24 & Nakagawa,M & 28 & Takatsuki, K & 20 \\
\hline Franchini, G & 71 & Murphy, EL & 67 & Mahieux, R & 23 & Taylor, GP & 27 & Watanabe, T & 19 \\
\hline Takatsuki, K & 70 & Soriano, V & 67 & Casoli, C & 23 & Ijichi, S & 27 & Sonoda, $\mathrm{S}$ & 18 \\
\hline Sonoda, S & 70 & Watanabe, T & 67 & Blattner, WA & 21 & Nagai, M & 25 & Bazarbachi, A & 17 \\
\hline Mahieux, R & 69 & Takatsuki, K & 66 & Gutiérrez, M & 21 & Umehara, F & 25 & Waldmann, TA & 16 \\
\hline Watanabe, T & 69 & Sonoda, S & 66 & Rosenblatt, JD & 21 & Eguchi, K & 24 & Maeda, Y & 16 \\
\hline
\end{tabular}

N.: number; Docs.: documents. 

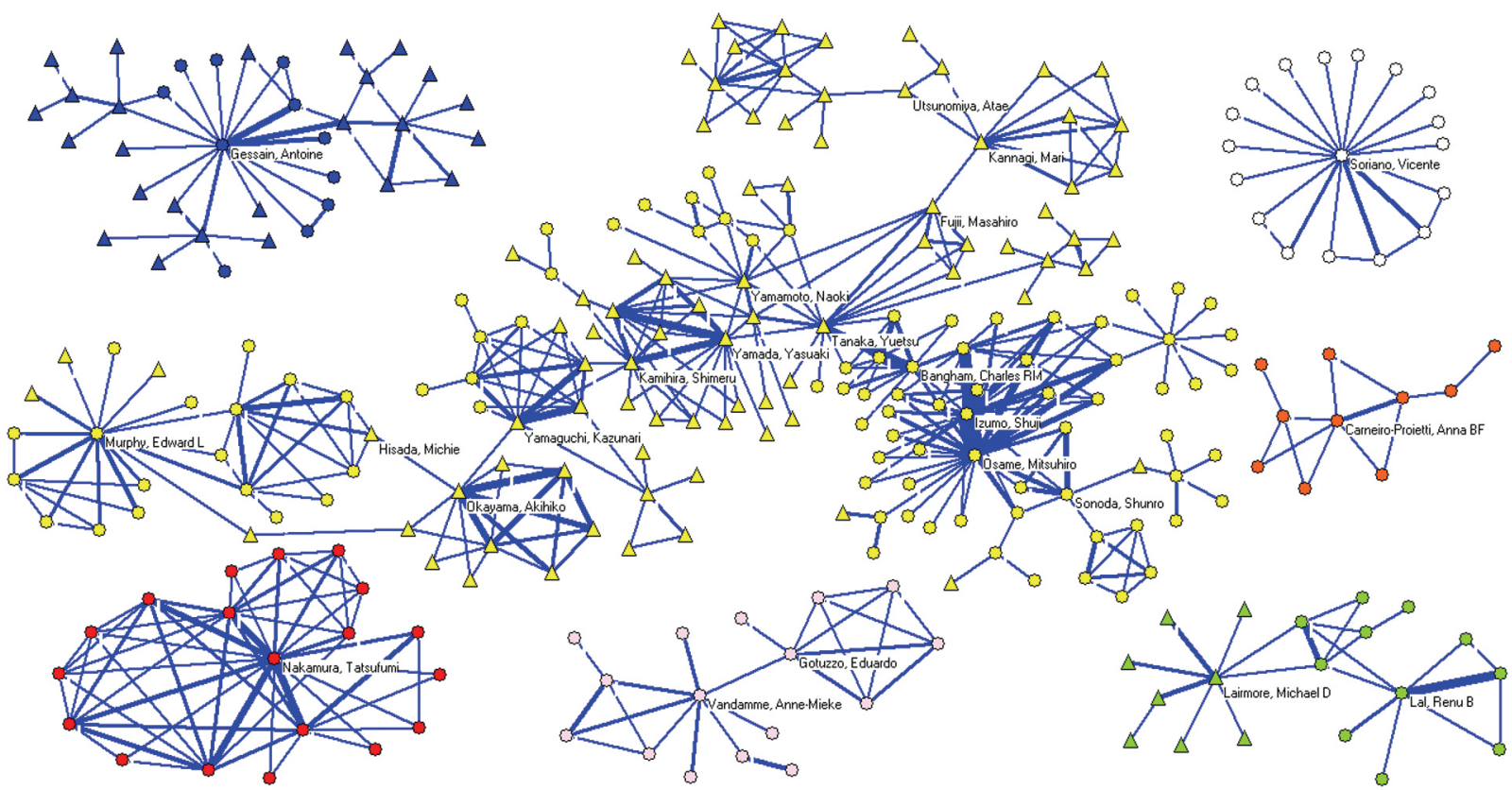

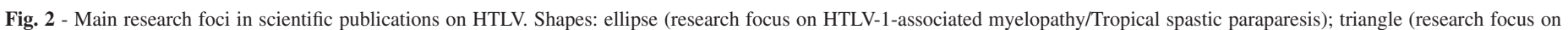
Adult T-cell leukemia/lymphoma).

pharmaceutical financial support is extremely low. Therefore, although the availability of new journals in PubMed focusing on retroviruses, like Retrovirology $y^{24}$, may provide a positive feedback for HTLV research papers, there is less interest in this field than before ${ }^{19,23}$.

Although most HTLV manuscripts are written in English (89.1\%), following the trends for scientific diffusion in the research field ${ }^{23}$, another relevant language was Japanese (5.1\%). HTLV is endemic in Japan ${ }^{3-5}$, which might explain the prevalence of this language with respect to others.

Original papers were the most commonly retrieved document type (approximately $77.8 \%$ ), similar to other bibliometric studies on virus research ${ }^{23}$. Although controlled trials offer the best evidence for medical intervention efficacy ${ }^{30}$, in this study they represented only $0.8 \%$ of the documents, which would explain the resulting absence of effective antiretroviral therapy for HTLV infection.

Japan was the leading country in publication output on HTLV. As HTLV is endemic in Japan ${ }^{3-5}$, this might explain the prevalence of this country with respect to others. USA, which was the second country, has excelled in virology $y^{19,22}$ as well as other biomedical fields ${ }^{31}$. France was the third country, with more HTLV publications than in any other biomedical field ${ }^{31-34}$, probably due to a higher relevance of virology research in this country.

HTLV is also endemic in South America, especially among several native peoples ${ }^{35,36}$. Brazil was the fourth country, and led scientific production on HTLV in Latin America. Moreover, this country has increased its overall production during the study period as well as its relative contribution. This can be attributed to a greater research projection for the future and the large population living there, as well as to the number of researchers and the development of the country's scientific system, which has become the main scientific reference for South America ${ }^{22,37}$. Brazil also has a large stake in neglected tropical diseases, which are a priority for public health due to their high incidence (Chagas diseases or Leishmaniasis) $^{34,38}$. In several bibliometric studies on other neglected diseases ${ }^{34,38}$, Brazil has been a leading country in South America, and is, to be more precise, important as a South American network core. Although HTLV is endemic to central Australia among indigenous Australians, virology and clinical aspects of HTLV infection remain poorly described and there are scanty scientific publications from Australia $^{39}$.

In HTLV-1 and ATLL, the leading countries were Japan and USA followed by France. In HTLV-2 the leading country was USA followed by Brazil and France. HTLV-2 research was less important among Japanese scientists, which is due to the fact that HTLV-2 infects intravenous drug users (IDUs) in USA and Europe, and Amerindian tribes in Latin American countries ${ }^{40}$.

In HAM/TSP, the leading country was Japan, followed by USA and Brazil. The HAM/TSP incidence density among HTLV-1-seropositive cases observed in current asymptomatic individuals in Brazil is higher than that in studies in other countries ${ }^{41,42}$. For intance, Brazilian scientists had a special relevance in research on HTLV with HAM/TSP ${ }^{27,41}$.

Asia and North America were the world's leading areas in scientific production on HTLV. In HTLV-2, the interest of research in European countries was greater than in Asian countries such as Japan. Europe, which has more IDUs, had more cases for HTLV infection, which consequently arouses interest in HTLV-2 research. Moreover, USA and Europe have a long tradition of agencies and institutions implementing research and health programs and lead in scientific production. North 
González-Alcaide G, Ramos JM, Huamaní C, Mendoza C, Soriano V. Human T-lymphotropic virus 1 (HTLV-1) and human T-lymphotropic virus 2 (HTLV-2): geographical research trends and collaboration networks (1989-2012). Rev Inst Med Trop Sao Paulo. 2016;58:11.

America, Japan and Europe are at the vanguard of scientific excellence and development, and should increase their collaboration with scientific publications in developing countries, especially publications in the field of HTLV from Latin America and the Caribbean.

The progressive growth in collaboration over the last few decades is one of the defining features of the evolution of science ${ }^{43,44}$. By applying SNA to coauthorship in scientific publications, we identified the existing research groups in the field and the principal investigators active in them. Within the networks, it is possible to distinguish a few nodes that stand out from the rest. These nodes, identified through centrality measures, represent a limited number of influential authors who act as intermediates, favoring cohesion between different areas of the network and facilitating a rapid connection (i.e. a minimal number of steps) between the researchers and groups that participate in the broader network. A few nodes play also an important role as "bridges" that connect different foci in the network. If these authors disappear, the overall connectivity of the network would diminish, and its effectiveness would be undermined ${ }^{45}$. Although there is no consensus on the exact significance of centrality measures, some studies have related these measures to the greater quantity or quality of research produced ${ }^{46}$; or they have been used as a predictor of preferential attachment by newcomers to the research community ${ }^{47}$.

We used the PubMed database because it is easily accessible and widely used; it uses a controlled vocabulary for indexing and recovering documents ${ }^{32,33,35}$, and the index journal in Medline has a certain criteria for quality ${ }^{33}$. However, the method we used may have several limitations, which have been explained in other publications ${ }^{4}$. For example, the database mainly includes journals published in English, and journals in other languages are less likely to be found in PubMed. However, this database has more non-English journals than the Web of Science database ${ }^{48}$. Another limitation is that in PubMed, only the first author's address appear in the journal articles, so it is not possible to estimate the quantity of articles from multinational collaborations. This may cause some problems when estimating research productivity from developing countries that work in collaboration with scientists from a developed country. Even though the bibliometric methodology used may present some limitations and the results could, in some way, be biased ${ }^{49,50}$, we believe that this study represents a useful tool for scientists and public health policy makers to plan and organize research in the field of HTLV.

\section{CONCLUSIONS}

Authors affiliated with institutions in Japan and USA led scientific production in HTLV research. Efforts should be made to help lowincome countries with the highest prevalence of HTLV to promote scientific research networks (collaborative platforms) with Japan, North American and/or European countries in order to increase research based on virology, epidemiology, and/or clinical implications of HTLV infection. HTLV infection is a life-long infection and is currently incurable and untreatable. For this reason, HTLV infection, as a neglected disease, would provide more focus on this condition, perhaps increasing the number of researchers in this field and promoting research collaboration, which could lead to the development of better treatment options for patients.

\section{ACKNOWLEDGMENTS}

We express our gratitude to Lorraine Mealing and Meggan Harris for their assistance in translation and editing.

\section{CONFLICT OF INTEREST}

The authors declare that there are no conflicts of interest.

\section{FINANCIAL SUPPORT}

Non-financial competing interests

\section{REFERENCES}

1. Poiesz B, Ruscetti FW, Gazdar AF, Bunn PA, Minna JD, Gallo RC. Detection and iso lation of type $\mathrm{C}$ retrovirus particles from fresh and cultured lymphocytes of a patient with cutaneous T-cell lymphoma. Proc Natl Acad Sci USA. 1980;77:7415-9.

2. de Thé G, Bomford R. An HTLV-I vaccine: why, how, for whom? AIDS Res Hum Retroviruses. 1993;9:381-6.

3. Hlela C, Shepperd S, Khumalo N, Taylor GP. The prevalence of human T-cell lymphotropic virus type 1 in the general population is unknown. AIDS Rev. 2009;11:205-14.

4. Watanabe T. Current status of HTLV-1 infection. Int J Hematol. 2011;94:430-4.

5. Proietti F, Carneiro-Proietti AB, Catalan-Soares BC, Murphy EL. Global epidemiology of HTLV-I infection and associated diseases. Oncogene. 2005;24:6058-68.

6. Treviño A, Benito R, Caballero E, Ramos JM, Parra P, Roc L, et al. HTLV infection among foreign pregnant women living in Spain. J Clin Virol. 2011;52:119-22.

7. Verdonck K, González E, Van Dooren S, Vandamme AM, Vanham G, Gotuzzo E. Human T-lymphotropic virus 1: recent knowledge about an ancient infection. Lancet Infect Dis. 2007;7:266-81.

8. Treviño A, García J, de Mendoza C, Benito R, Aguilera A, Ortíz de Lejarazu R, et al. Prevalence of HTLV-1/2 infections in Spain: a cross-sectional hospital-based survey. AIDS Res Hum Retroviruses. 2010;26:861-4

9. Araujo A, Hall WW. Human T-lymphotropic virus type II and neurological disease. Ann Neurol. 2004;56:10-9.

10. Biswas HH, Engstrom JW, Kaidarova Z, Garratty G, Gibble JW, Newman BH, et al. Neurologic abnormalities in HTLV-I- and HTLV-II-infected individuals without overt myelopathy. Neurology. 2009;73:781-9.

11. Casoli C, Pilotti E, Bertazzoni U. Molecular and cellular interactions of HIV-1/HTLV coinfection and impact on AIDS progression. AIDS Rev. 2007;9:140-9.

12. Gastaldello R, Hall WW, Gallego S. Seroepidemiology of HTLV-I/II in Argentina: an overview. J Acquir Immune Defic Syndr. 2004;35:301-8.

13. Lehky T, Flerlage N, Katz D, Houff S, Hall WH, Ishii K, et al. Human T-cell lymphotropic virus type II-associated myelopathy: clinical and immunologic profiles. Ann Neurol. 1996;40:714-23.

14. Roucoux D, Murphy E. The epidemiology and disease outcomes of human T lymphotropic virus type II. AIDS Rev. 2004;6:144-54.

15. Mahieux R, Gessain A. HTLV-3/STLV-3 and HTLV-4 viruses: discovery, epidemiology, serology and molecular aspects. Viruses. 2011;3:1074-90 

and collaboration networks (1989-2012). Rev Inst Med Trop Sao Paulo. 2016;58:11.

16. Calattini S, Chevalier SA, Duprez R, Bassot S, Froment A, Mahieux R, et al. Discovery of a new human T-cell lymphotropic virus (HTLV-3) in Central Africa. Retrovirology. $2005 ; 2: 30$.

17. Morel CM, Serruya SJ, Penna GO, Guimarães R. Co-authorship network analysis: a powerful tool for strategic planning of research, development and capacity building programs on neglected diseases. PLoS Negl Trop Dis. 2009;3:e501.

18. Rosas SR, Kagan JM, Schouten JT, Slack PA, Trochim WM. Evaluating research and impact: a bibliometric analysis of research by the NIH/NIAID HIV/AIDS clinica trials networks. PLOS ONE. 2011;6:e17428.

19. Zheng HC, Yan L, Cui L, Guan YF, Takano Y. Mapping the history and current situation of research on John Cunningham virus: a bibliometric analysis. BMC Infect Dis. 2009;9:28.

20. Safahieh H, Sanni SA, Zainab AN. International contribution to Nipah Virus Research 1999-2010. Malays J Libr Inf Sci. 2012;17:35-47

21. Chen DM, Mao KY, Jiang HB. A bibliometric analysis of the international literatures on avian influenza. AJSMMU. 2013;34:607-11

22. Luchs A. Profile of Brazilian scientific production on A/H1N1 pandemic influenza. Ciênc Saude Colet. 2012:17:1629-34.

23. Lin HW, Yu TC, Ho YS. A systemic review of human papillomavirus studies: global publication comparison and research trend analyses from 1993 to 2008. Eur J Gynaecol Oncol. 2011;32:133-40.

24. Verdonck K, Gotuzzo E. Bibliometric description of the literature on HTLVregistered in PubMed over the past ten years. Retrovirology. 2011;8(Suppl 1):A247.

25. Ngudi DD, Kuo YH, Van Montagu M, Lambein F. Research on motor neurone diseases konzo and neurolathyrism: trends from 1990 to 2010. PLoS Negl Trop Dis. 2012;6:e1759.

26. Zihlmann, KF, de Alvarenga, AT, Casseb, J. Living invisible: HTLV-1-infected persons and the lack of care in public health. PLoS Negl Trop Dis. 2012;6:e1705.

27. Casseb J. Is human T cell lymphotropic type 1 (HTLV-1)-associated myelopathy/ tropical spastic paraparesis (HAM/TSP) syndrome a neglected disease? PLoS Neg Trop Dis. 2009;3:e487

28. World Development Indicators. (cited 2014 Jul 24). Available from: <http://data. worldbank.org/data-catalog/world-development-indicators>.

29. Undata. United Nations Statistics Division. Composition of macro geographical (continental) regions, geographical sub-regions, and selected economic and other groupings. (cited 2014 Jul 24). Available from: <https://unstats.un.org/unsd/methods/ m49/m49regin.htm>

30. Jones CW, Hunold KM, Isaacs CG, Platts-Mills TF. Randomized trials in emergency medicine journals, 2008 to 2011. Am J Emerg Med. 2013;31:231-5.

31. Schoonbaert D, Demedts V. Analysis of the leprosy literature indexed in Medline (1950-2007). Lepr Rev. 2008;79:387-400.

32. López-Illescas C, de Moya-Anegón F, Moed HF. The actual citation impact of European oncological research. Eur J Cancer. 2008;44:228-36.

33. Ramos JM, Padilla S, Masiá M, Gutiérrez F. A bibliometric analysis of tuberculosis research indexed in PubMed, 1997-2006. Int J Tuberc Lung Dis. 2008;12:1461-8.

34. Ramos JM, González-Alcaide G, Gascón J, Gutiérrez F. Mapping of Chagas disease research: analysis of publications in the period between 1940 and 2009. Rev Soc Bras Med Trop. 2011;44:708-16.
35. Blas MM, Alva IE, García PJ, Cárcamo C, Montano SM, Mori N, et al. High prevalence of human T-lymphotropic virus infection in indigenous women from the Peruvian Amazon. PLOS ONE. 2013;8:e73978.

36. Gessain A, Cassar O. Epidemiological aspects and world distribution of HTLV-1 infection. Front Microbiol. 2013;3:388.

37. Almeida EA, Ramos Junior AN, Correia D, Shikanai-Yasuda MA. Rede brasileira de atenção e estudos na co-infecção Trypanosoma cruzi/HIV e em outras condições de imunossupressão. Rev Soc Bras Med Trop. 2009;42:605-8.

38. González-Alcaide G, Huamaní C, Park J, Ramos JM. Evolution of coauthorship networks: worldwide scientific production on leishmaniasis. Rev Soc Bras Med Trop 2013;46:719-27.

39. Einsiedel L, Cassar O, Bardy P, Kearney D, Gessain A. Variant human T-cell lymphotropic virus type 1c and adult T-cell leukemia, Australia. Emerg Infect Dis. 2013;19:1639-41

40. Biglione M, Vidan O, Mahieux R, de Colombo M, de los Angeles de Basualdo M, Bonnet M, et al. Seroepidemiological and molecular studies of human T cel lymphotropic virus type II, subtype b, in isolated groups of Mataco and Toba Indians of northern Argentina. AIDS Res Hum Retroviruses. 1999;15:407-17.

41. Facchinetti LD, Araújo AQ, Chequer GL, de Azevedo MF, de Oliveira RV, Lima MA Falls in patients with HTLV-I-associated myelopathy/tropical spastic paraparesis (HAM/TSP). Spinal Cord. 2013;51:222-5.

42. Romanelli LC, Caramelli P, Martins ML, Gonçalves DU, Proietti FA, Ribas JG, et al Incidence of human $\mathrm{T}$ cell lymphotropic virus type 1-associated myelopathy/tropical spastic paraparesis in a long-term prospective cohort study of initially asymptomatic individuals in Brazil. AIDS Res Hum Retroviruses. 2013;29:1199-202.

43. Falagas ME, Karavasiou AI, Bliziotis IA. A bibliometric analysis of global trends of research productivity in tropical medicine. Acta Trop. 2006;99:155-9.

44. Keiser J, Utzinger J. Trends in the core literature on tropical medicine: a bibliometric analysis from 1952-2002. Scientometrics. 2005;62:351-65.

45. Borgatti SP. Identifying sets of key players in a social network. Comput Math Organ Theory. 2006;12:21-4.

46. Yan E, Ding Y. Applying centrality measures to impact analysis: a coauthorship network analysis. J Am Soc Inf Sci Technol. 2009;60:2107-18.

47. Abbasi A, Hossain L, Leydesdorff L. Betweenness centrality as a driver of preferential attachment in the evolution of research collaboration networks. J Informetr. 2012;6:403-12

48. Rollin RL, Darmoni S, Caillard JF, Gehanno JF. Searching for high-quality articles about intervention studies in occupational health: what is really missed when using only the Medline database? Scand J Work Environ Health. 2010;36:484-7.

49. Sevinc A. Multilingual approach to "Web of Science". J Natl Med Assoc. 2005;97:116

50. Vioque J, Ramos JM, Navarrete-Muñoz EM, García-de-la-Hera M. A bibliometric study of scientific literature on obesity research in PubMed (1988-2007). Obes Rev. 2010;11:603-11

Received: 26 February 2015

Accepted: 16 April 2015 